OAK

$r$ RIDGE

NATIONAL LABORATORY

$y^{p}$

UNION

GARBIDE

$$
\text { (a) }
$$$$
\text { - }
$$

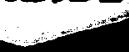

ORNL-5617

\section{An Autoradiographic Study of Actinide Sorption on Climax Stock Granite}
G. W. Beali
G. D. O'Kelley
B. Allard 
Contract No. H-7405-eng-26

\author{
Chemistry Division
}

AN AUTORADIOGRAPHIC STUDY OF ACTINIDE SORPTION ON CLIMAX STOCK GRANITE

G. H. Beall, G. D. O'Kelley and B. Allard

Date Published: June 1980

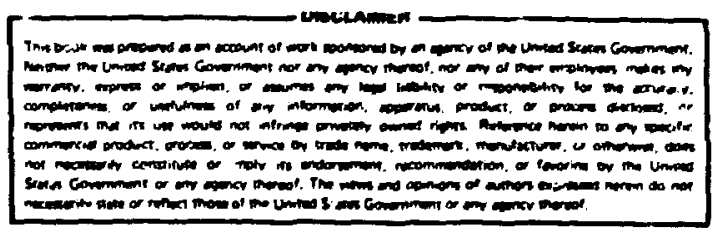

Prepared by the OAK RIDGE MATIONAL LABORATORY

Oak Ridge, Tennessee 37830 operated by LNION CARBIDE CORPORATION for the DEPARTMENT OF ENERGY 
CONTENTS

\section{Page}

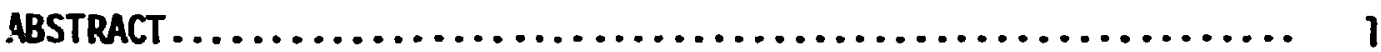

INTRODUCTION....................................... 2

EXPERIMENTAL..................................... 2

RESULTS AMD DISCUSSION.............................. 8

CONCLUSIONS....................................... 19

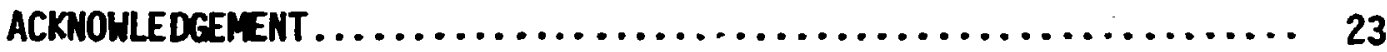

REFERENCES...................................... 24 
AN AUTORADIOGRAPHIC STUDY OF ACTINIDE SORPTION ON CLIMAX STOCK GRANITE G. H. Beall, G. D. O'Kelley, and B. Allard ${ }^{\dagger}$

\begin{abstract}
An autoradiographic technique that employed an arrangement for placing in firm contact Polaroid sheet film, a scintillator screen, and the radioactive face of a specimen was applied to a study of the sorption of americium, neptunium, plutonium, and uranium on $\mathrm{Cl}$ imax Stock granite under varying conditions of $\mathrm{pH}$ and Eh. Qualitative agreement was found between the sorption of americium on crushed, pure minerals and on the minerals comprising the specimen of Climax Stock graiite. The observations also supported a mechanism for reduction of $N p(V)$ to $N_{p}(I V)$ and $P u(V I)$ to Pu(IV) by Fe(II)containing minerals. There was no evidence for reduction of U(VI) by the $\mathrm{Fe}(I I)$-containing minerals, although the uranium, assumed to be present as $\mathrm{UO}_{2}{ }^{2+}$, appeared to be the only actinide species to exhibit sorption by a simple, cation-exchange mechanism at particular mineral sites. Some implications of these results for nuclear waste isolation are discussed briefly.

KEYMORDS: Actinide sorption, Autoradiography, Nuclear waste.
\end{abstract}

\footnotetext{
"Present address: Radian Corporation, 3500 Shoal Creek Blvd., Austin, TX 78758.

tpresent address: Chalmers Untverstty of Technology, S-4i296, Goteborg. Sweden.
} 


\section{IKTRODUCTIOI}

The sorption of actinides on pure minerals or crushed rocks has been studied by many investigators in connection with various concepts of nuciear waste isolation. Such measurements have usually employed ei ther batch equilibration or colum techniques. Two major objections have been raised to the conclusions regarding sorption on whole rocks derived from such experiments. Some investigators have suggested that studies conducted on pure minerals can not be employed to predict the sorption on whole rocks, since factors such as grain boundary and surface area effects are ignored. A second related objection is that, in the past, many studies on crushed rocks which have attempted to correlate certain sorption mechanisas with the individual minerals contained in them have required rather indirect reasoning, with inconclusive results. An example of this latter sort of study is the work of Franci:; and Bondietti ${ }^{1}$ on the reduction of Np and TC by minerals containing ferrous iron. These questions have prompted this investigation, in which an autoradiographic technique was employed to study the sorption of actinide ions on Climax Stock granite in several groundwater systems, frum wich qualitative comparisons could be made between literature data on pure minerals and the sorption patterns observed.

\section{EXPERIMEMTAL}

The $\mathrm{Cl}$ imax Stock granite used in these studies was obtained from R. J. Serne of Battelle Northwest Laboratories in connection with the Waste Isolation Safety Assessment Progran. The granite was sawed into slabs approximately $3 \mathrm{~cm}$ on an edge and $3 \mathrm{~mm}$ thick. The slabs 
were polished on a lapidary wheel with corundum polishing compound. Based on sorption measurements on corundum, ${ }^{2}$ the small contamination of the granite by the abrasive would have a negligible effect on sorption of the actinides. Optical photographs were then taken to be used in identification of the mineral components.

All sorption experiments were carried out on the same slab of Climax Stock granite, with final dimensions of $2.7 \times 3.1 \times 0.3 \mathrm{~cm}$. Before each experiment, the polished face was cleaned with $6 \mathrm{M} \mathrm{HCl}$, followed by washing with distilled water. Occasionally, an additional stej of decontamination was included, using a solution of detergent and EDTA. Final repolishing began with grade 180 or 320 emery paper, followed by finer grades of abrasive, and was completed with grade 600 emery paper. The fresh surface was washed with distilled water, drled with tissue, and quickly mounted in the sorption apparatus. This procedure resulted in negligible residual radioactive contamination from one experiment to another.

The simple apparatus for sorption experiments is sketched in Fig. 1. All experiments employed as the aqueous medium 50 or $100 \mathrm{~mL}$ of a synthetic groundwater with the concentrations of principal constituents listed in Table 1. In equilibrium with ambient air, the $\mathrm{pH}$ was 27.8 and was largely determined by the equilibrium between $\mathrm{CO}_{2}$ and $\mathrm{HCO}_{3}^{-}$ion. For experiments under anoxic conditions, $\mathrm{N}_{2}$ gas was bubbled through the solution to remove $\mathrm{O}_{2}$ and $\mathrm{CO}_{2}$. In a typical experiment under anoxic conditions, before the granite specimen was lowered into contact with the solution, the pH attained a steady value of $\sim 9.3$. 


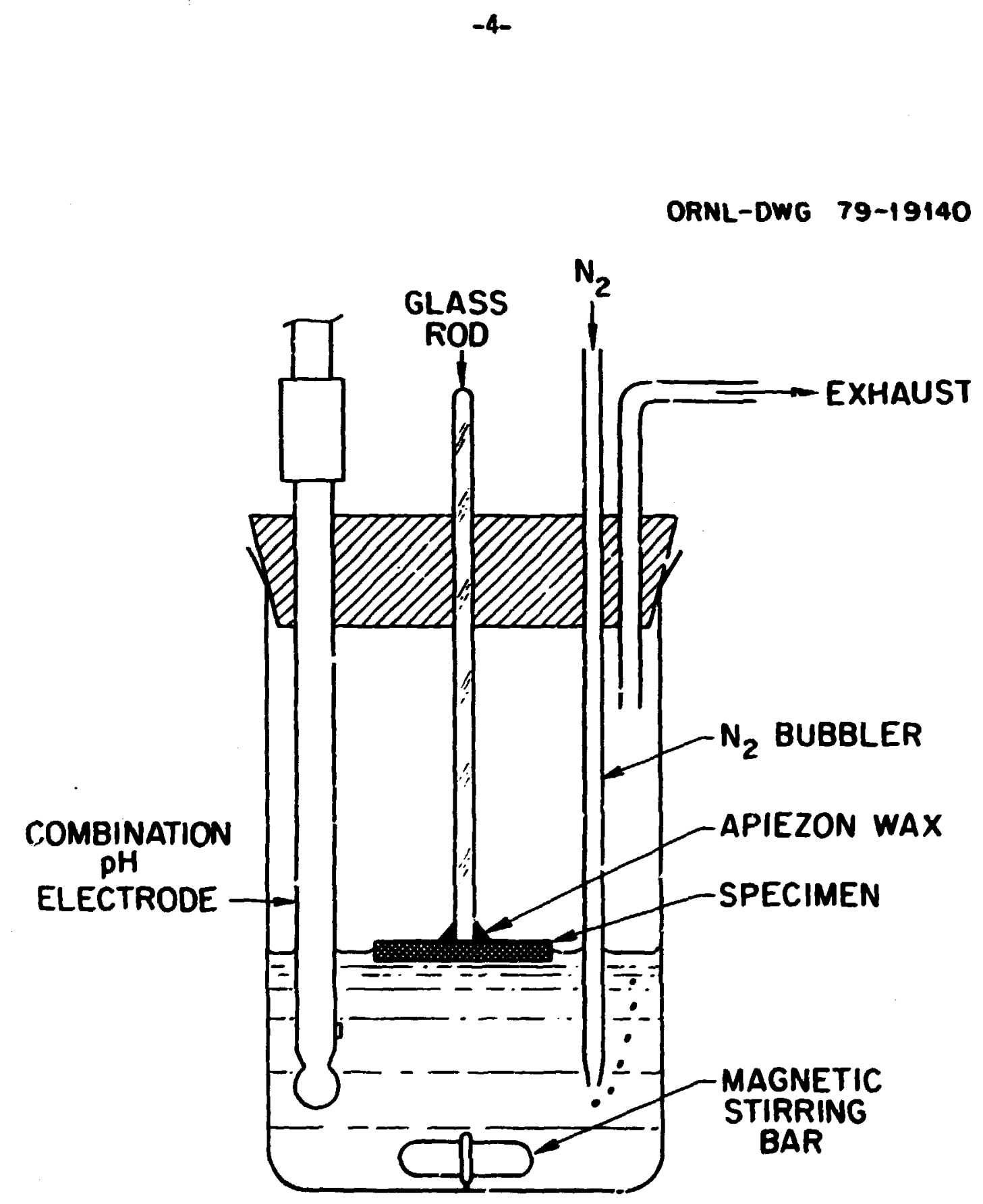

Fig. 1. Apparatus for sorption of actinides on rock specimens. 
Table 1. Composition of Artificial Groundwater ${ }^{\mathrm{a}}(\mathrm{pH}=7.8)$

\begin{tabular}{|c|c|c|c|}
\hline Species & $\begin{array}{c}\text { Concentration } \\
\mathrm{mg} / \mathrm{L}\end{array}$ & Species & $\begin{array}{c}\text { Concentration } \\
\mathrm{mg} / \mathrm{L}\end{array}$ \\
\hline $\mathrm{HCO}_{3}^{-}$ & 123 & $\mathrm{Ca}^{2+}$ & 18 \\
\hline $\mathrm{SO}_{4}{ }^{2-}$ & 9.6 & $\mathrm{Mg}^{2+}$ & 4.3 \\
\hline $\mathrm{Cl}^{-}$ & 70 & $\mathrm{~K}^{+}$ & 3.9 \\
\hline $\mathrm{SiO}_{2}$ (total) & 12 . & $\mathrm{Na}^{+}$ & 65 \\
\hline
\end{tabular}

Radioactive concentrations were chosen to insure adequate deposition on the specimen for an autoradiograph. The nuclides used and their concentrations were: ${ }^{233} \mathrm{U}, 6.4 \times 10^{-7} \mathrm{M}$; ${ }^{237} \mathrm{~Np}, 4.2 \times 10^{-5} \mathrm{M}$;

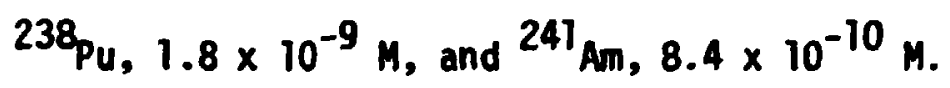

In a typical experiment, the apparatus of Fig. 1 was assenbled with the granite specimen positioned above the solution until all adjustments ware complete and the $\mathrm{pH}$ readings attained a constant value. To achieve stable, anoxic conditions requitred from 5 to 20 hours with the modest flow rates of $\mathrm{N}_{2}$ gas used here, since it was considered importunt to avoid premature transfer of solution to the specimen by spattering. The bubler nozzle was withdrawn from the solution and positioned with the tip a few $\mathrm{mm}$ above the surface of the aqueous phase, and $N_{2}$ gas fiow was maintained at $20.03 \mathrm{~m}^{3} \mathrm{hr}^{-1}$ during the sorption experiment. The glass rod was adjusted to 
tamerse the specimen to a depth of $1.5-2.0 \mathrm{~m}$ in the groundrater solution. Typical sorption experiments were carried out for 20-21 hours, uniess long-ten effects were being investigated. This would yield kd values approximately 803 of those found for batch equilibratians of 5 days. Ottrer experimental details are given on the captions to the autoradiographs displaved below.

Following a sorption experiment, the specimen was washed with distilled water and dried with tissue. It was then installed in the autoradiograph "camera," whose essentials are show in Fig. 2. The Polaroid type $574 \times 5$ sheet film was loaded into a Polarotd 545 film holder, mounted in the wall of a light-tight wetal box containing the other components of Fig. 2. To load the sheet $\mathrm{film}$, the pressure plate was retracted by a lever system actuated from outside. When the envelope was pulled back to uncover the film, the pressure plate was then pressed down so that the radioactive face of the specimen, the ZnS scintillator on owlar filim, and the Polaroid film, were all in firm contact. A lever and weight arrangement was employed to orovide constant contact pressure during the exposures. The plastic foam pad was found necessary to insure adequate alignment because the specimen was not of precisely uniform thickness.

. The high sensitivity of this method for alpha particles arises from the use of the scintillator as a transducer, together with 3000

\footnotetext{
"Polarofd Corporatton, Cambridge, m 02139.
} 
ORNL-DWG 79-19139

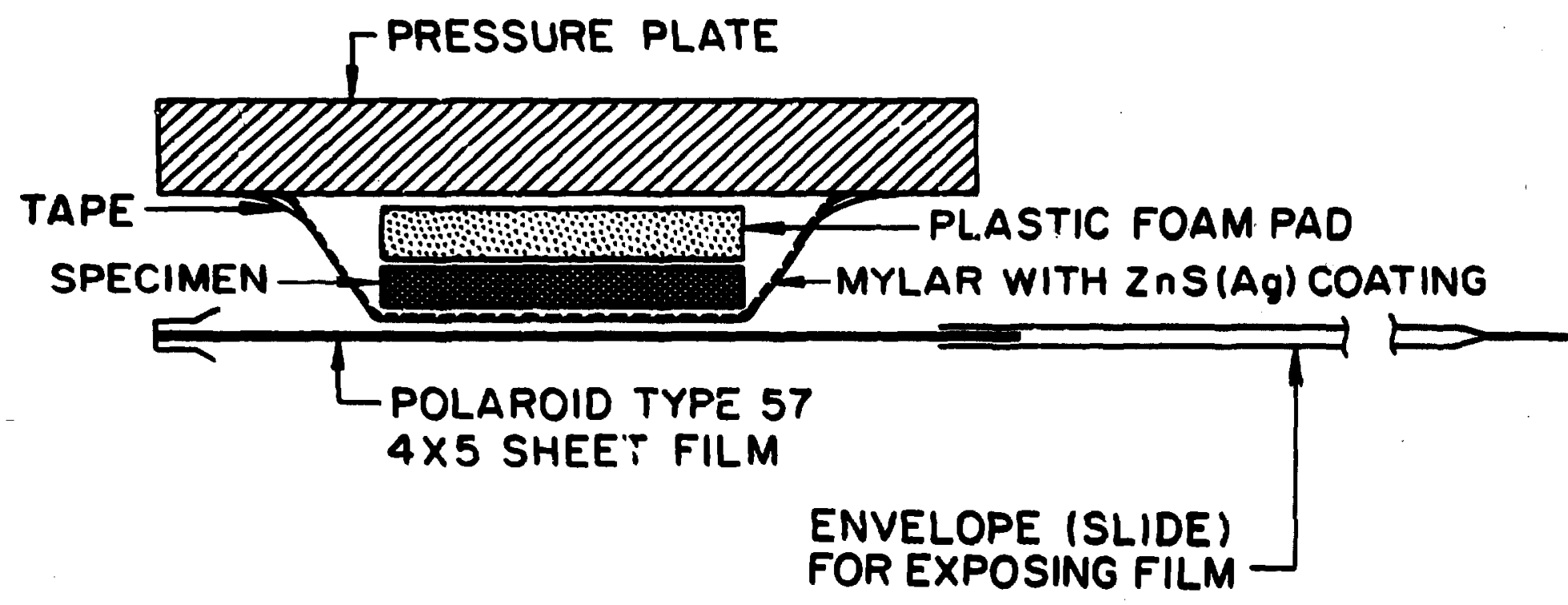

Fig. 2. Simplified diagram of autoradiograph camera, showing essentiai parts.. 
ASA panchromatic filn. The scintillator sheet is standard silveractivated zinc sulfide [ZnS(Ag)] coated on one side of 0.004-in. $(0.1 \mathrm{~m})$ mlar film. This scintillator film is used extensively in low-level alpha-particle counting. Several other types of Polaroid photographic film were tried, but type 57 yielded by far the best resolution at these light levels. The response of the film appeared to be highly non-linear with respect to time.

The arrangement used in these experiments has proved to be very convenient and reproducible. Dupiicate experiments yield qualitatively indistinguishable results. Once the scintillator screen, specimen, and plastic foam pad are attached to the pressure plate with office tape, any desired number of exposures can be made without exposing the scintillator to room light. This is an important advantage, because after exposure to intense room light, about one hour is required for a long-lived phosphorescence in the $\mathrm{ZnS}(\mathrm{Ag})$ scintillator to decay to a usabie level.

\section{RESULTS AND DISCUSSION}

The Climax Stock granite employed in this study is composed primarily of quartz, feldspar, biotite, and pyrite. The mineralugical composition of this granite ${ }^{3}$ is given in Table 2. In Fig. 3, a reflected light optical photo of the Climax Stock granite, as well as a labelled tracing of the mineral grains, can be seen. In the optical photo the white grains are pyrite $\left(\mathrm{FeS}_{2}\right)$, the light grey are * Avaflable from William B. Inhnson \& Assocfates, Inc., Research Park, Montvilie, WJ 07045. 
(a)

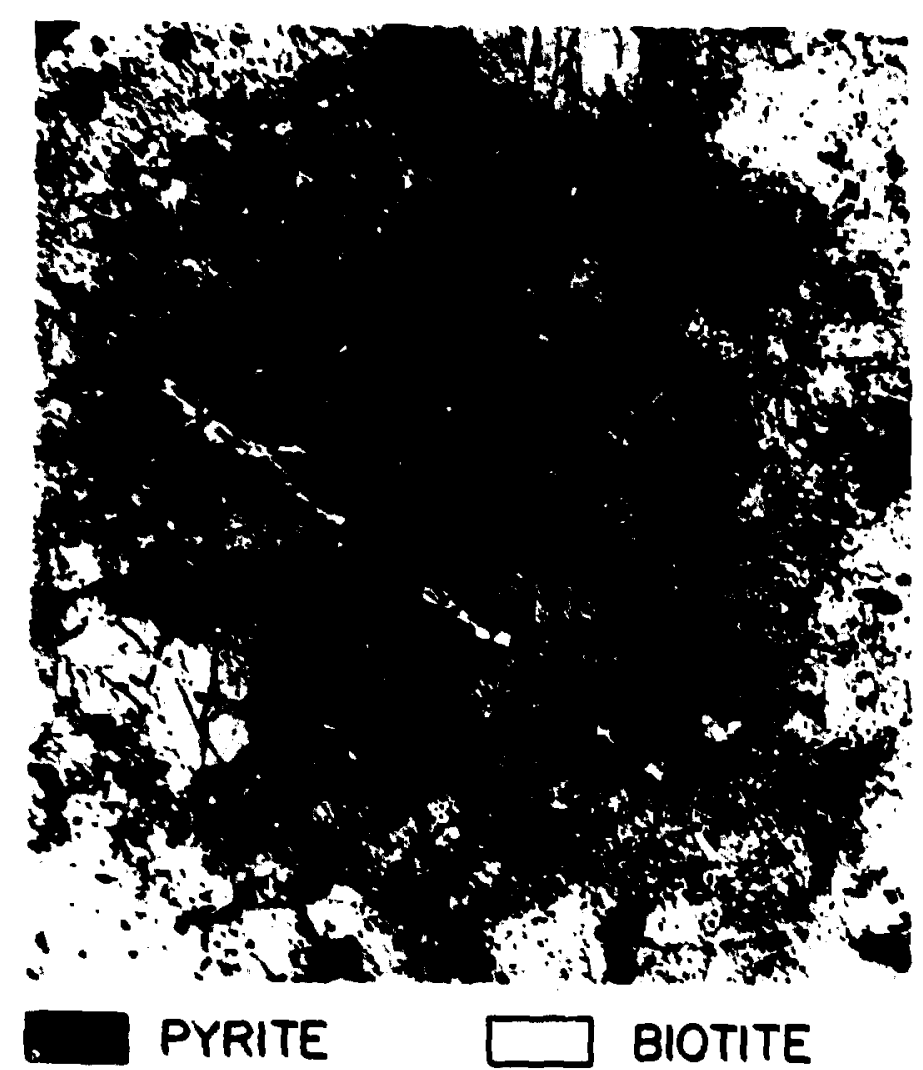

(b)

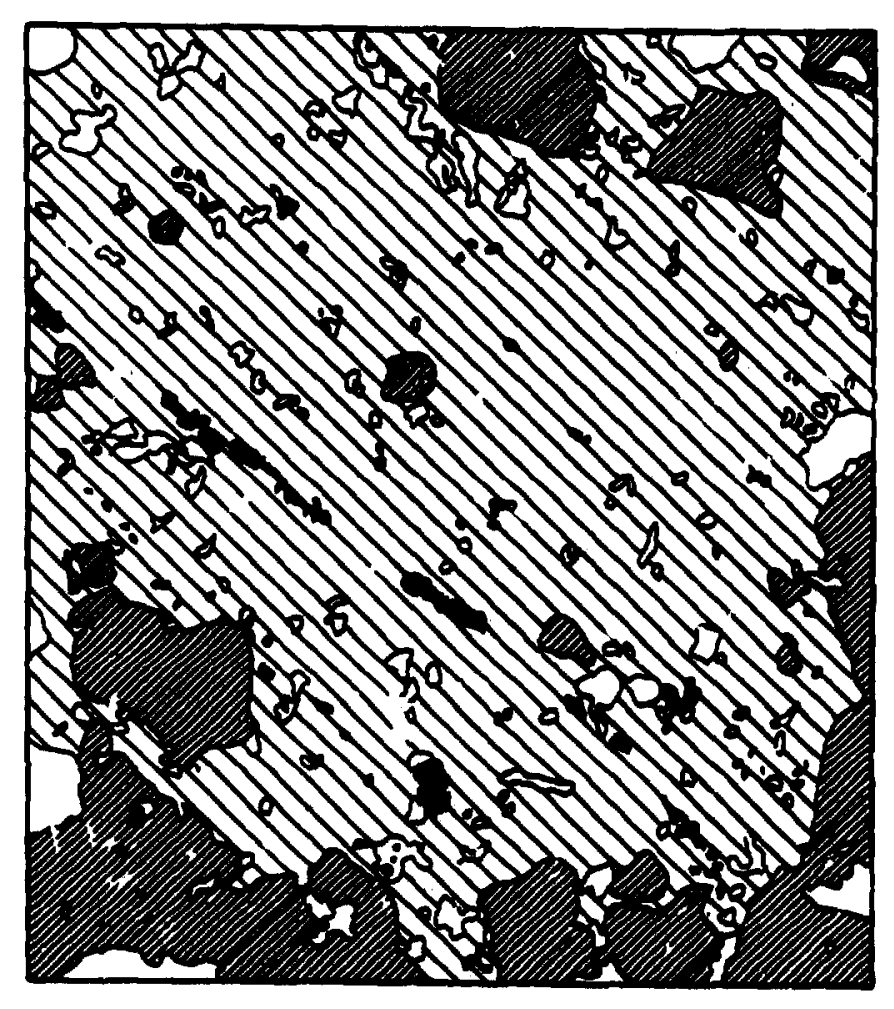

WIIIA MAJOR QUARTZ GRAINS

DIV FELDSPARS AND SMALL QUARTZ GRAINS

Fig. 3. Mineralogy of the Climax Stock granite specimen. (a) Optical photograph in reflected ilght; (b) tracing of (a) coded to identify principal minerals. 
Table 2. Composition of Climax Stock Granite ${ }^{a}$

fineral

Andesine

Quartz

Microcline

Bistite

Pyrite

${ }^{\text {a }}$ Reference 3.
Chemical Composition

$\left(\mathrm{Ha}_{2.3^{\mathrm{Ca}}}{ }_{1.8^{K}} \mathrm{O}_{.01}\right)\left(\mathrm{Al_{5.4 }}{ }^{, \mathrm{Si}} 10.5^{\mathrm{C}_{32}}\right.$ $\mathrm{SiO}_{2}$

$\left(\mathrm{K}_{3.9}\right)\left(\mathrm{Al} \mathrm{I}_{4.1, \mathrm{Si}} 11.97\right) \mathrm{O}_{32}$

$\mathrm{K}_{2.2}\left(\mathrm{Hg}_{2.61} \mathrm{Fe}_{3.4}\right)\left(\mathrm{Fe}_{0.7}, \mathrm{Al}_{0.45}, \mathrm{Ti}_{0.4}\right)$

$\left(\mathrm{Si}_{5.7}, \mathrm{Al}_{2.3}\right) \mathrm{C}_{24}(\mathrm{OH})_{2}$

$\mathrm{FeS}_{2}$
Nt. $X$

$46 \%$

$28 \%$

$15 \%$

$10 \%$

$1 \%$

quartz, the dark groy are feldspars, and the black av 2 biotite. These various compolients are cleariy identified in the tracing. In Fig. 4, a classification of rock types is presented based on mineral composition and grain size. The area that has been shaded fits the mineralogical co, ition of the Climax Stock best, and since the rock is fairly coarse-grained, it could more appropriately be called a morizonite. The only major deviation rineralogically is the amphibole region, which is almost non-existent in this rock. This granite tus chosen specifically for these studies because of its grain size, its reasonably simple, representative mineralogical composition, and its two ferrous minerals.

This granite also exhibited substantial trace impurities of clay minerals that formed from weathering of the feldspars (B. Erdal ${ }^{4}$ ). These clays appeared to be most abundant along cracks in the grantte. 


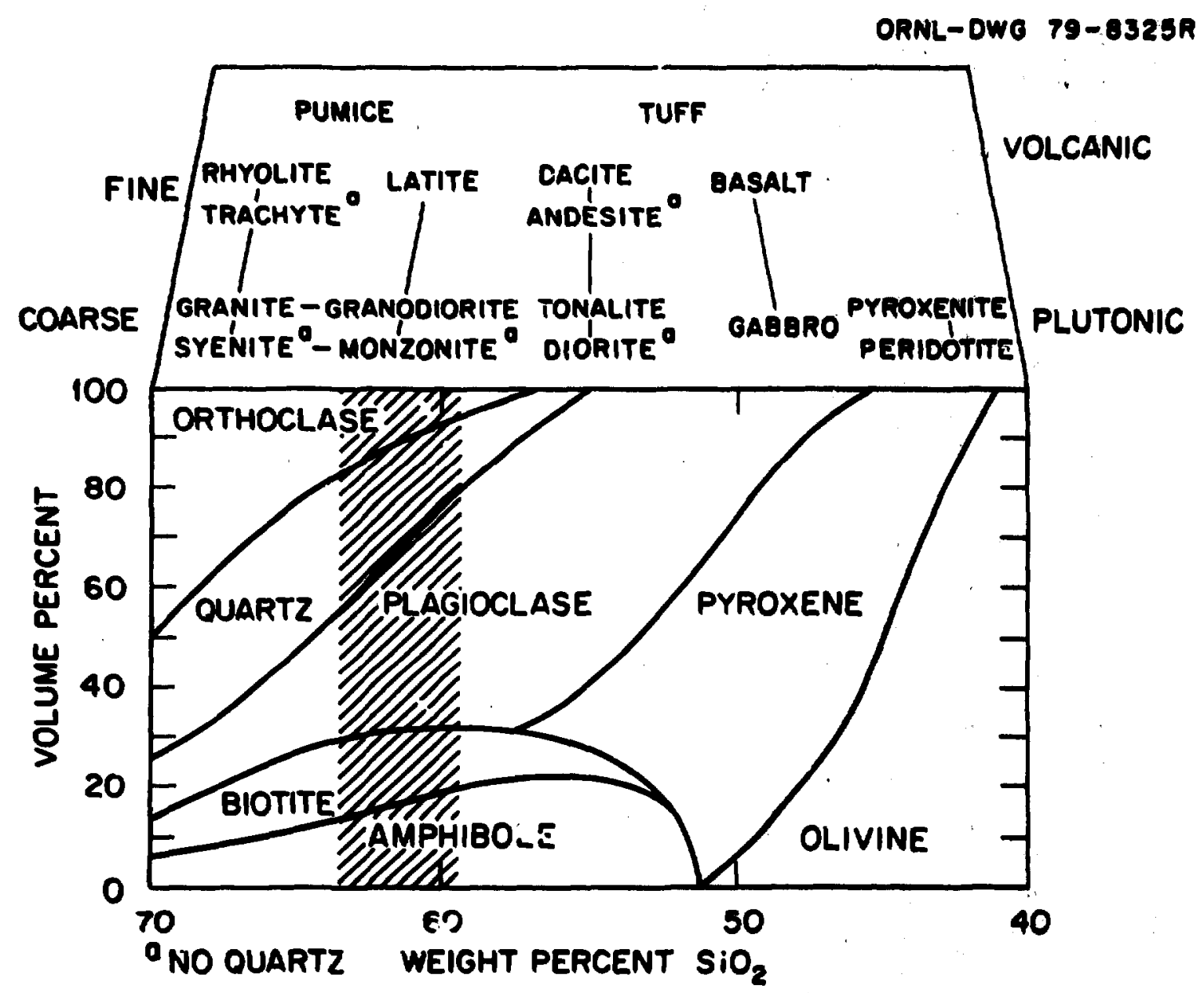

Fig. 4. Classification of rock. types according to mineral composition and grain stze. The shaded area includes the composition of Climax Stock granite. 
The first actinide chosen for study was anericium. This choice was due to the fact that the trivalent state is very stable and a large body of data exists for its sorption on pure minerals. 2,5 In Fig. 5 are giver autoradiographs following the sorption of arericium on Climax Stock granite under aerated and nitiogen-pirged conditions. It appears that slightly reducing condit.10ns do not simificantly affect the sorption of the americium. Examining the aerated sorption in wore detail one finds that there is general sorption over the whole rock surface, but that the pyrite grains and biotite grains sorb wuch more stronjiy; the feldspars exhibit lower sorption; and finally, quartz exhizits almost no sorption. Table 3 contains the distribution coefficients of Am on pyrite, biotite, quartz, and feldspars at a pH of 8.0. The biotite and pyrite are approximately the same, followed by feldspar, and quartz last. Extrenely good quaitative agreenent between the whole rock and pure mineral measurements is seen. There

Table 3. Distribution Coefficients for Am on Pure Minerals

Mineral

Biotite

Pyrfte

Feldspars

Quartz

apeference 2.
$\mathrm{Kd}\left(\mathrm{m}^{3} / \mathrm{kg}\right)$ DH $=8.0$

1.1

0.85

0.3

0.1 
OAnu-OW' R-18c02

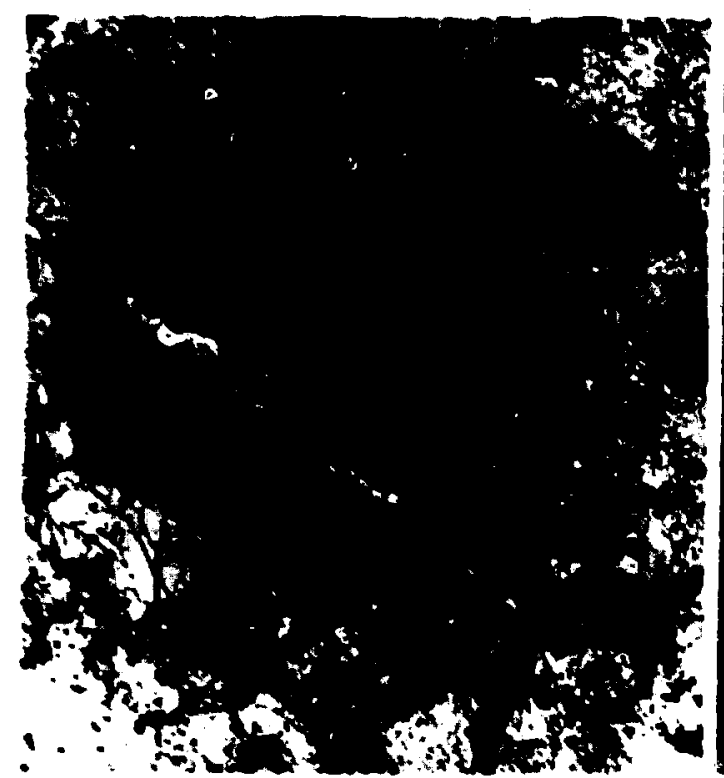

(a)

CLIMAX STOCK GRANITE

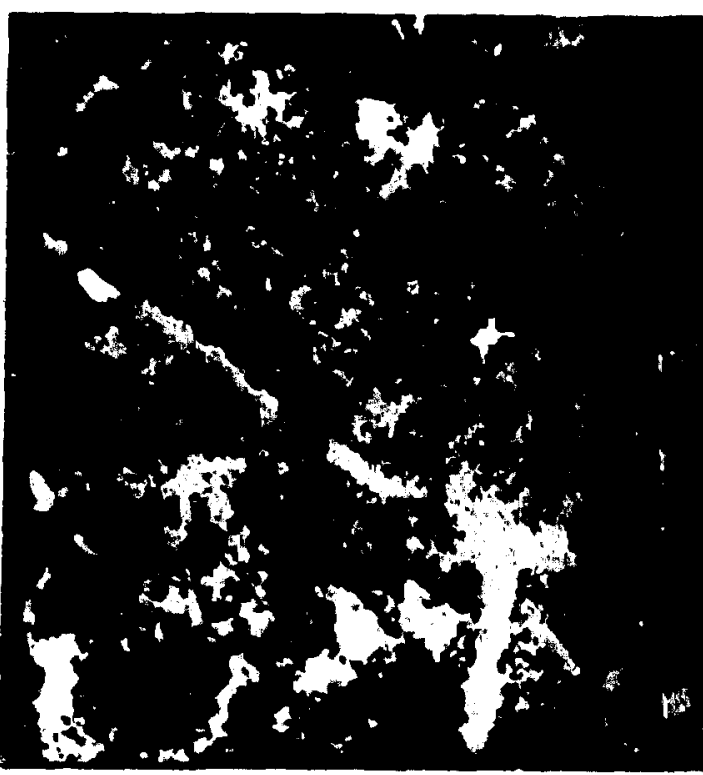

(b)

\section{Am IN AERATED} SOLUTIDN

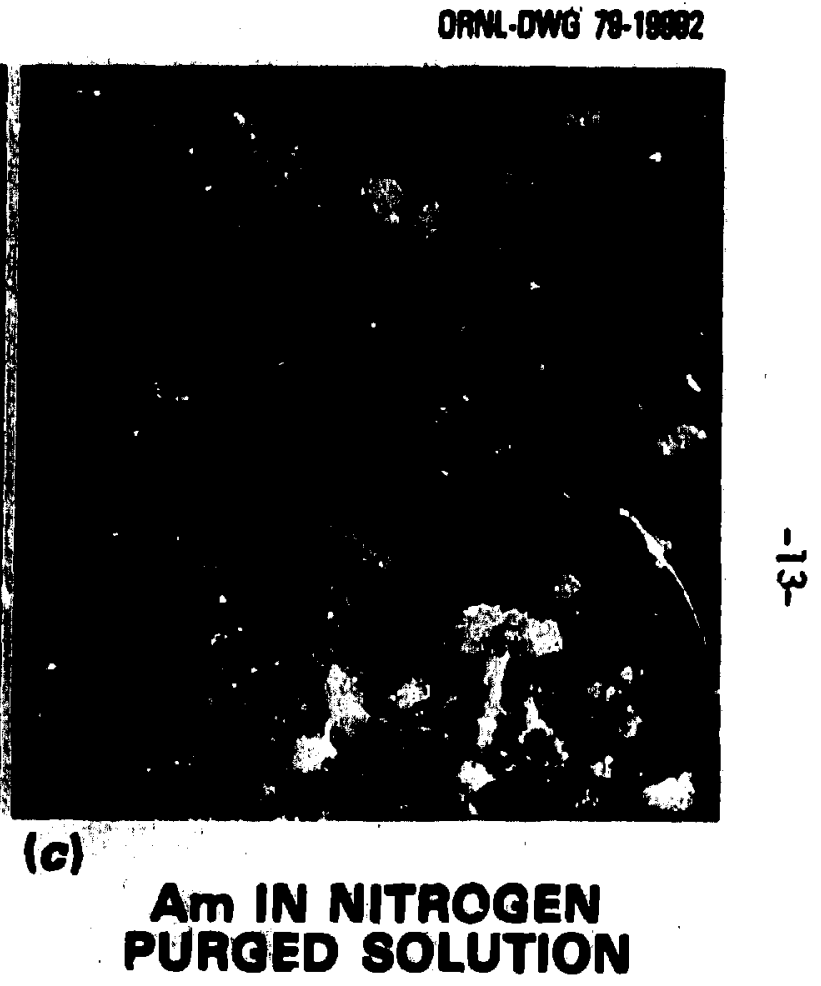

Fig. 5. Sorption of americium from synthetic groundwater. (a) Optical photograph as in Fig. 3(a); (b) autoradiograph after sorption of americium from an aerated solution (exposure $1 \mathrm{~min}$ ); (c) autoradiograph after sorption of americium from a solution purged with nitrogen $(3 \mathrm{~min})$. 
appear to be no grain boundary eflcets at all, but there are soue obvious effects from cracks. In the optical photo one can see a large crack running from the pyrite grain in the lower right hand comer of the slab dom to the lomer edge of the granite; indeed, this can be seen in the autoradiograph. This crack effect may be explained by an objervation, mentioned earlier, by workers at Los Alamos Scientific Laboratory 4 that there are substantial anounts of clay material present in this particular granite due to weathering of the feldspar. This would also correlate well with the sorption isotherms that have been observed for sorption of Am on pure ciay minerals. 2

The next element of interest is neptunium. In the solutions employed for these studies, the $\mathrm{Np}$ is expected to exist as the $\mathrm{NpO}_{2}^{+}$ cation. Figure 6 displays the effects of sorption of Np on Climax Stock granite from aerated and nitrogen-purged solutions. A third autoradiograph is shown, from an experiment in which the surface of the granite was oxidized with $\mathrm{H}_{2} \mathrm{O}_{2}$ prior to exposure to the $\mathrm{No} \mathrm{solu-}$ tion. The autoradiograpli of this oxidized surface exhibits general sorption across the whole surface that is not specific for any mineral. In contrast, the sorption of $\mathrm{Np}$ on the fresh surface of the granite under aerated conditions shows strong sorption of the Mp on certain minerals. These minerals turn out to be the Fe(II)-containing minerals pyrite and biotite. There is still some background sorption on the quartz and feldspar, but in contrast to the previously described autoradiograph, the background sorption is much less. The third autoradiograph, from an experiment under nitrogen-purged conditions, 


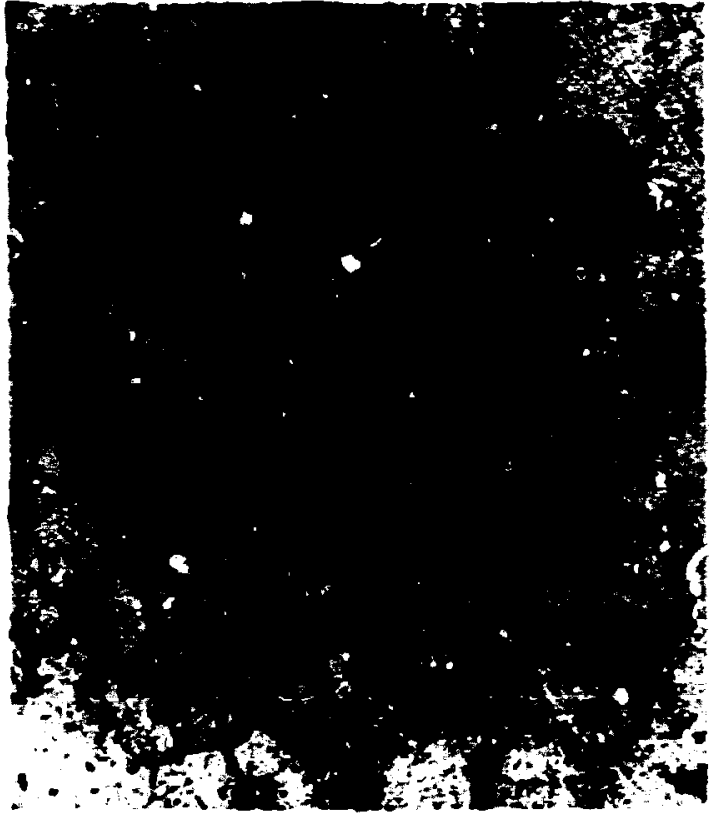

(a) CLMAX STOCK gRANITE

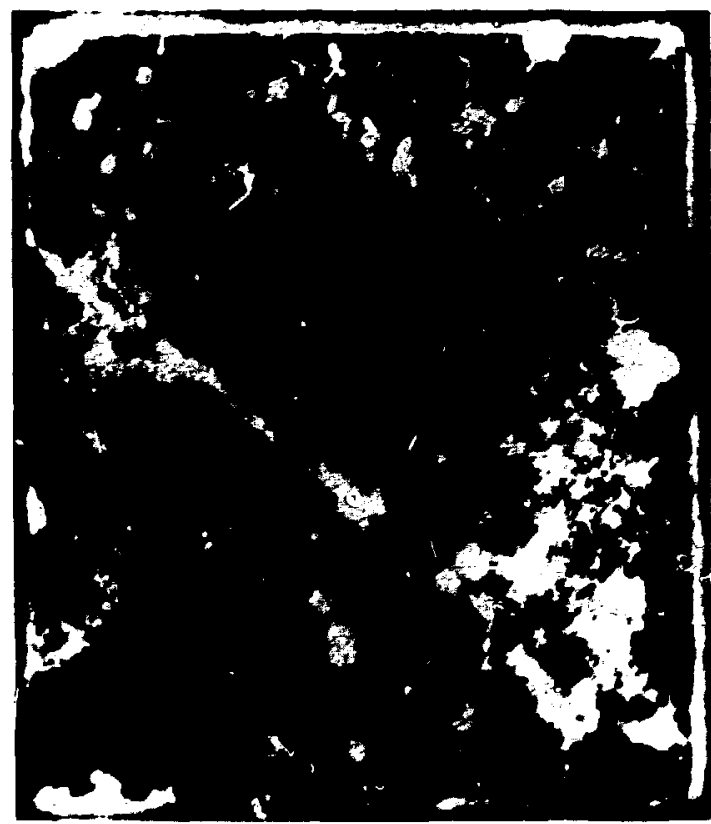

(c) ND IN AERATED SOLUTION

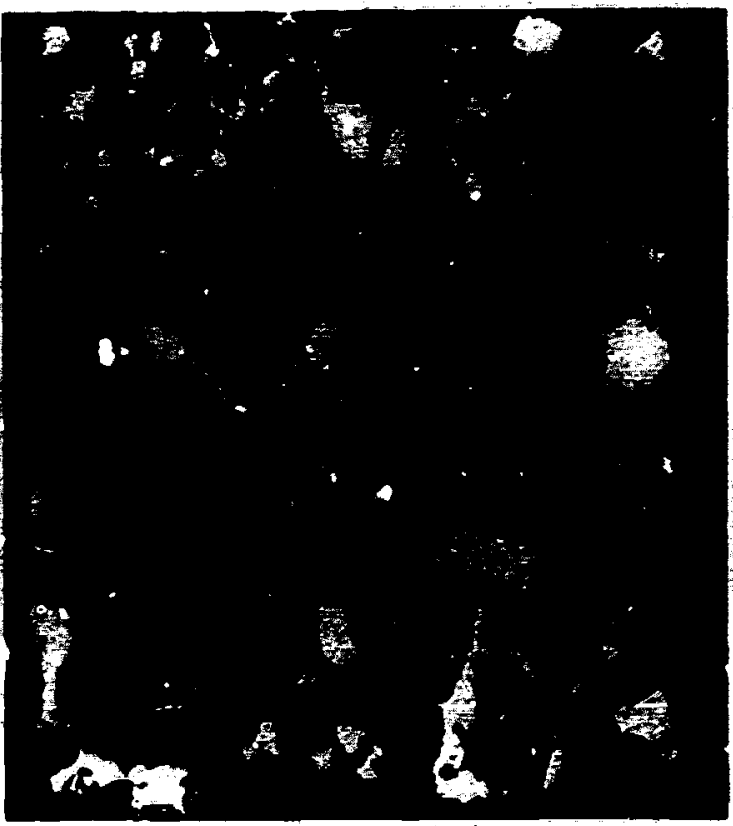

(b) NP IN NITROGEN PURGED SOLUTION

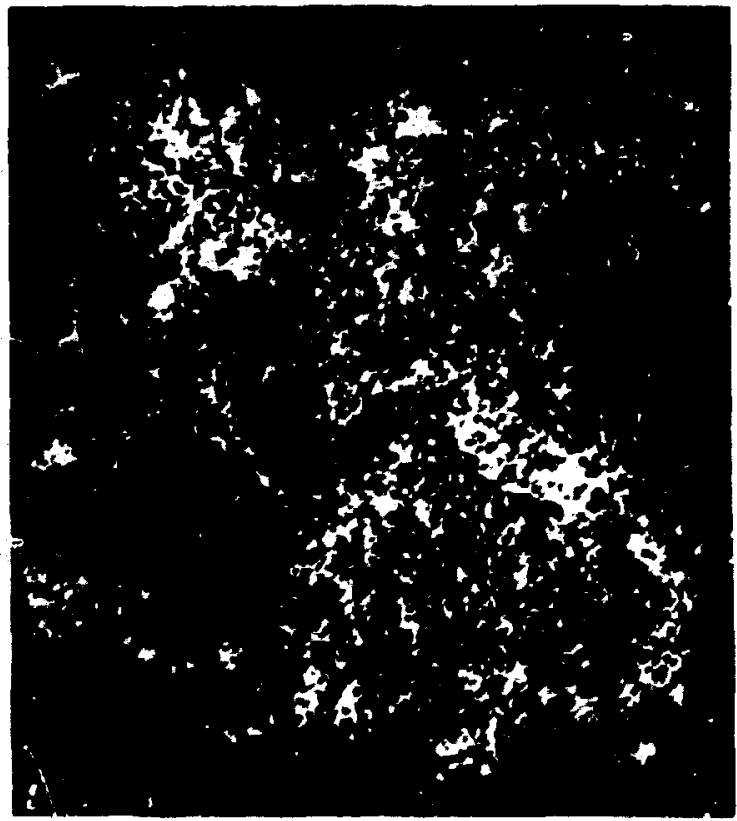

In NP ON OXIDIZED SURFACE

Fic. 6. Sorption of neptunfum from synthetfc groundwater. (a) Optfcal photograph of spectmen for compartson; (b) autoradtograph after sorption from nitrogen-purged solution (exposure $30 \mathrm{~m}$ ); (c) autoradiograph after sorption from aeratad solution $(2 \mathrm{~h})$; (d) autoradiograph after sorption from an aerated solution on surface treated previously with $\mathrm{H}_{2} \mathrm{O}_{2}(30 \mathrm{~m})$. 
exhibits even stronger sorption on the two minerals pyrite and biotite, and the general background sorption is substantially less. Thise large changes in sorption as the oxidizing or reducing conditions of the solution change, and the strong correlation of the sorption with the $\mathrm{Fe}$ (II)-containing minerals, suggest that the mechanism of sorption ni.t likely involves retuetion of $\mathrm{MpO}_{2}^{+}$to the much less soluble Mp(IV) by Fe(II).

The third element investigated was uranium, expected to exist in solution primarily as the very soluble cation $\mathrm{LO}_{2}{ }^{2+}$, which gemerally exhibits low distribution coefficients for most minerals. Autoradiographs of uranium sorbed on an oxidized granite surface and on an untreated surface from aerated and nitrogen-purged solutions are displayed in Fig. 7. The uranium is not observec to sorb significantly on any of the minerals except biotite. This sorption does not appear to be related to a reduction reaction with $\mathrm{Fe}(\mathrm{II})$. This conclusion is supported by two observations. The first is that al though the Fe(II)-containing mineral biotite sorbs uranium, pyrite does not; and second, the sorption is not affected by oxidizing or reducing conditions of the solution. The sorption of uranium on biotite appears to be associated with the layered structure of the biotite and its relatively large cationexchange capacity of $17 \mathrm{mg} / \mathrm{kg}$ versus $0.2 \mathrm{mg} / \mathrm{kg}$ for quartz. This type of sorption is supported by the fact that when the surface of the granite is polished to remove the uranium sorbed on it, many more treatments are required to remove it completely. Further evidence that this is, indeed, a cation excharige phenomenon is presented in Fig. 8. The ${ }^{233} U$ was sorbed on the granite in groundwater overnight 


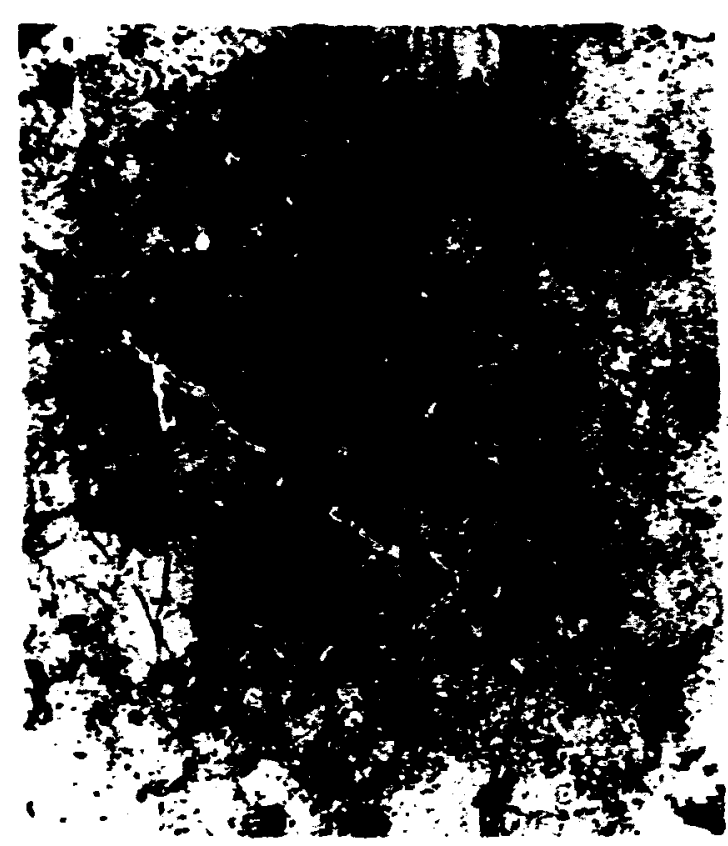

(a) CLIMAX STOCK GRANITE

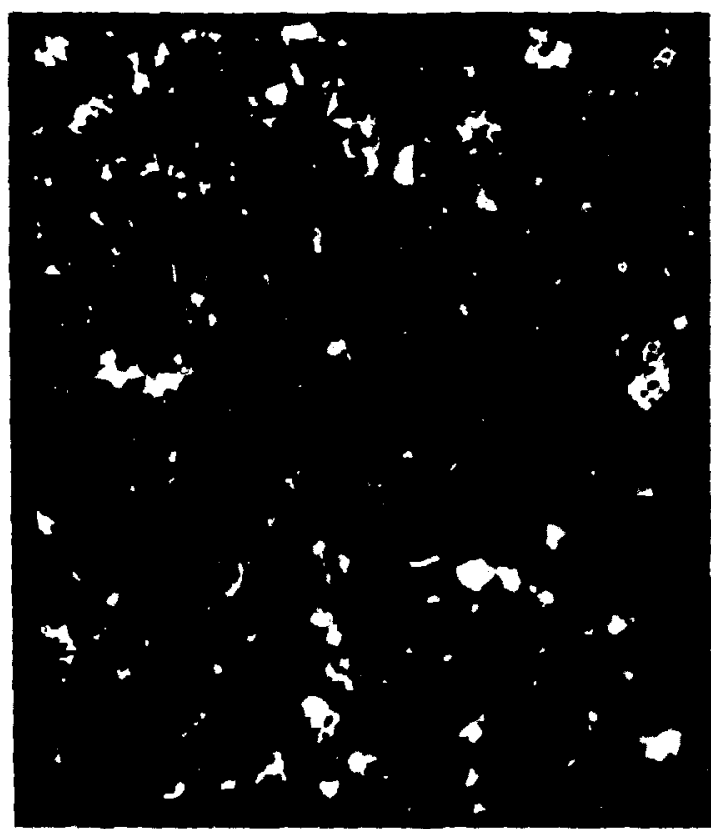

(c) U IN AERATEO SOLUTION

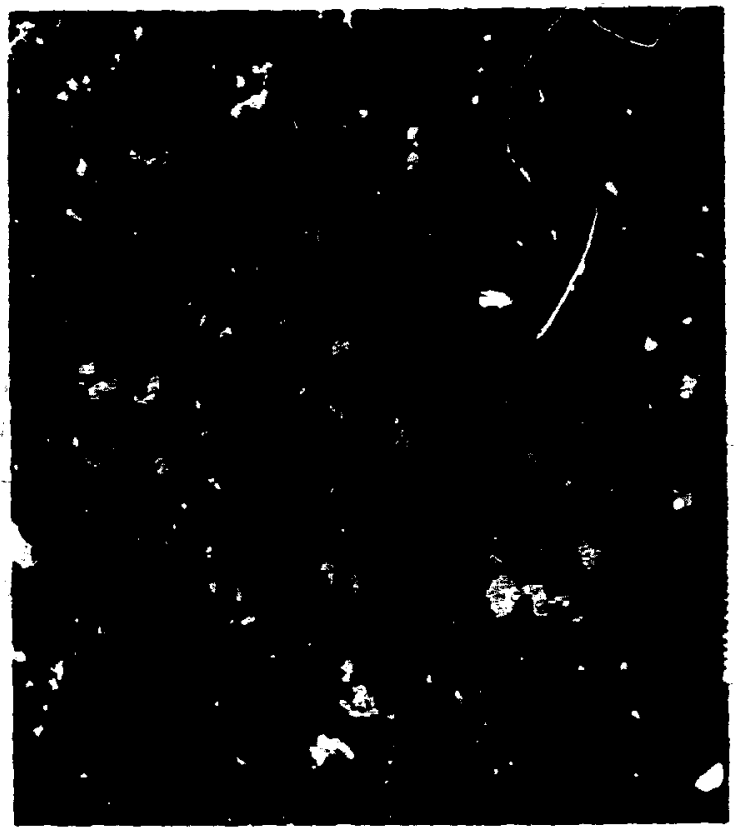

(b) U IN NTROGEN PURGED SOLUTION

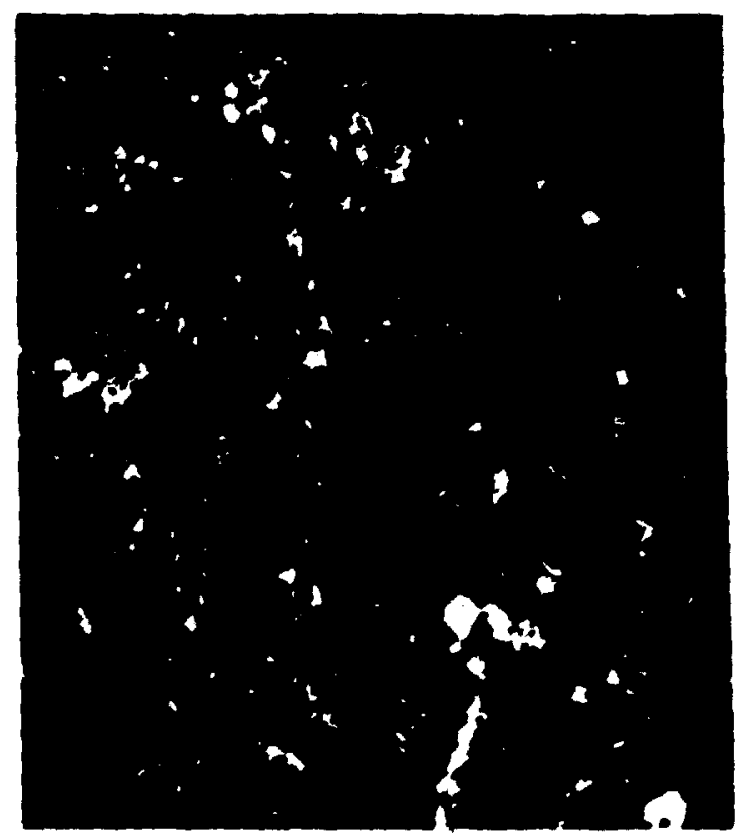

(d) U ON OXIDIZED SURFACE

Fig. 7. Sorption of uranium from synthetic groundwater. (a) Optical photograph of specimen for comparison; (b) autoradiograph after sorption from a nitrogen-purged solution (exposure, $15 \mathrm{~m}$ ); (c) autoradiograph after sorption from an aerated solution $(15 \mathrm{~m})$; (d) autoradiograph after sorption from an aerated solution on specimen treated previousiy with $\mathrm{H}_{2} \mathrm{O}_{2}(15 \mathrm{~m})$. 
ORNL.OWG 79.19986

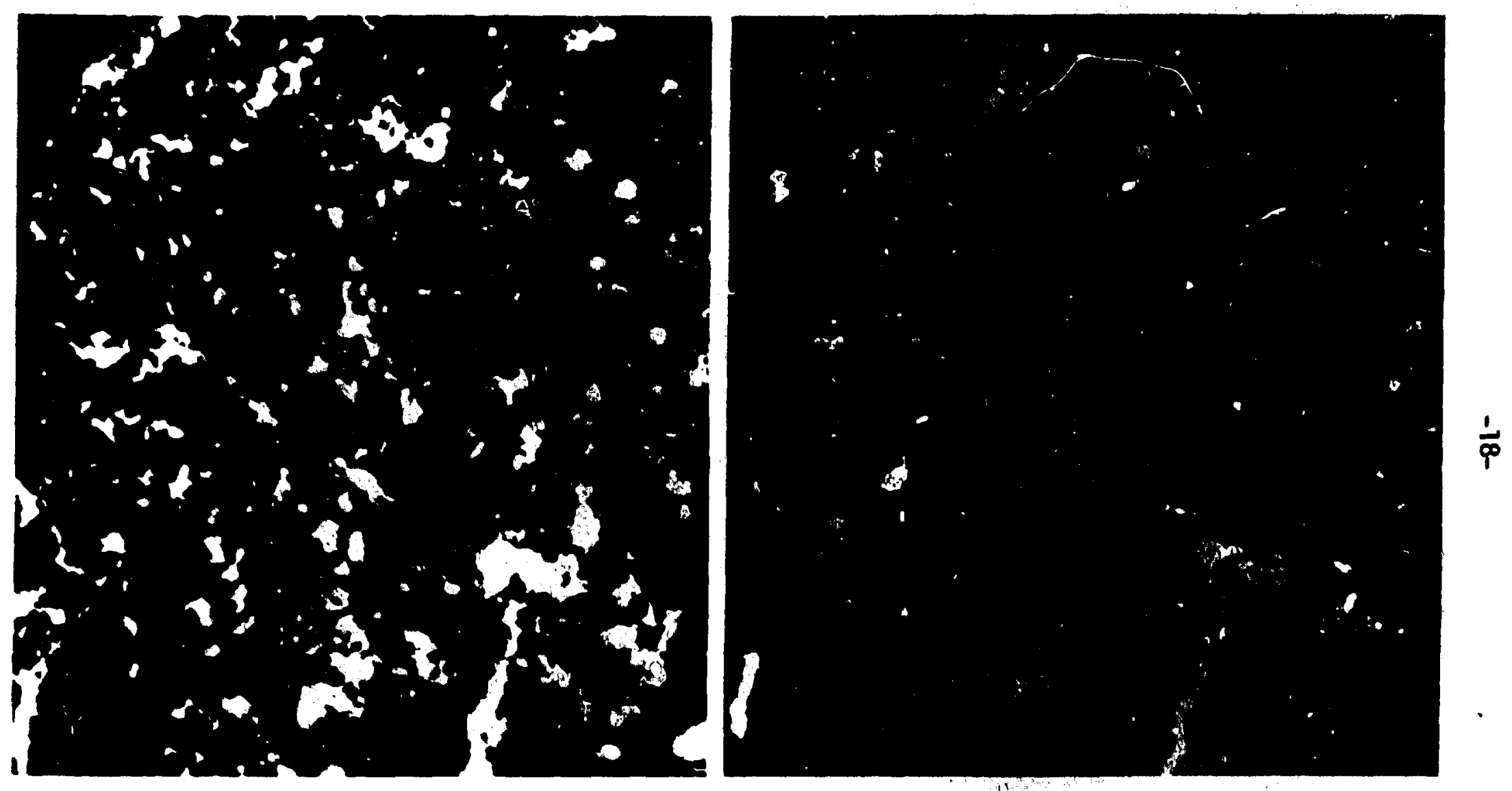

(a) U SORBED IN GROUNDWATER

(b) U SORBED IN $4 M$ NaCl

Fig. 8. (a) Autoradiograph after sorption of uranium from aerated groundwater; (b) autorantagraph after spectmen from (a) was re-1mmersed in the groundwator which had been adjusted to $4 \mathrm{MaCl}$. Exposure, $25 \mathrm{~m}$ each. 
and an autoradiograph taken, then sufficient $\mathrm{MaCl}$ was added to the groundwater to make it a $4 \mathrm{M} \mathrm{MaCl}$ solution. The granite was refmersed for a time equal to the previous experiment. As can clearly be seen, the ${ }^{233} \mathrm{~V}$ desorbed in qualitative agreement, with simple cation exchange behavior.

The last element to be studied was plutoniun, which was expected to be predominantly in the tetravalent state and, therefore, quite insoluble. In Fig. 9, autoradiographs are presented for Pu sosted on the Climax Stock granite from aerated and nitrogen-purged solutions and from a solution of Pu oxidized with $\mathrm{O}_{3}$. There appeared to be little effect of aerated or reducing conditions on the sorption. The sorption does exhibit some specificity for the Fe(II) minerals, but the predominant pattern is a general sorption across the entire surface. This is consistent with the behavior that would be expected for $\mathrm{PuO}_{2}$, but implies the presence of some $\mathrm{PuO}_{2}{ }^{2+}$. The sorption from the $\mathrm{O}_{3}$ treated solution, in which $\mathrm{PuO}_{2}{ }^{2+}$ should be the predominant species, does exhibit strong correlation with the Fe(II)-containing minerals, implying a reduction mechanism similar to that seen for $\mathrm{NpO}_{2}^{+}$.

\section{CONCLUSIONS}

In Fig. 10, the Eh vs $\mathrm{PH}$ trends expected ${ }^{6}$ for $\mathrm{Pu}, \mathrm{Np}$, and $\mathrm{U}$ are presented along with a field showing the range of values of Eh and pH prevalent in deep granitic mines. The autoradiographic experiments are consistent with a range of Eh and $\mathrm{pH}$ such that Am should be trivalent; Np should be pentavalent but reduced by Fe(II)-containing minerals; U should be hexavalent; and Pu should be tetravalent, but could be reduced from its hexavalent state by Fe(II)-containing minerals. To satisfy all of these conditions, the Eh and pH region 


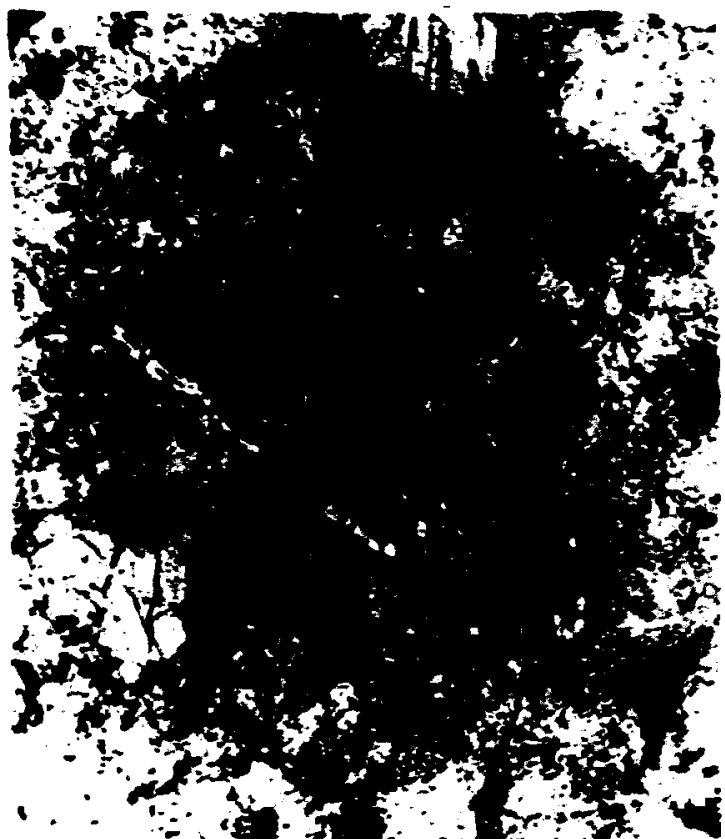

(a) clumax stock grantte

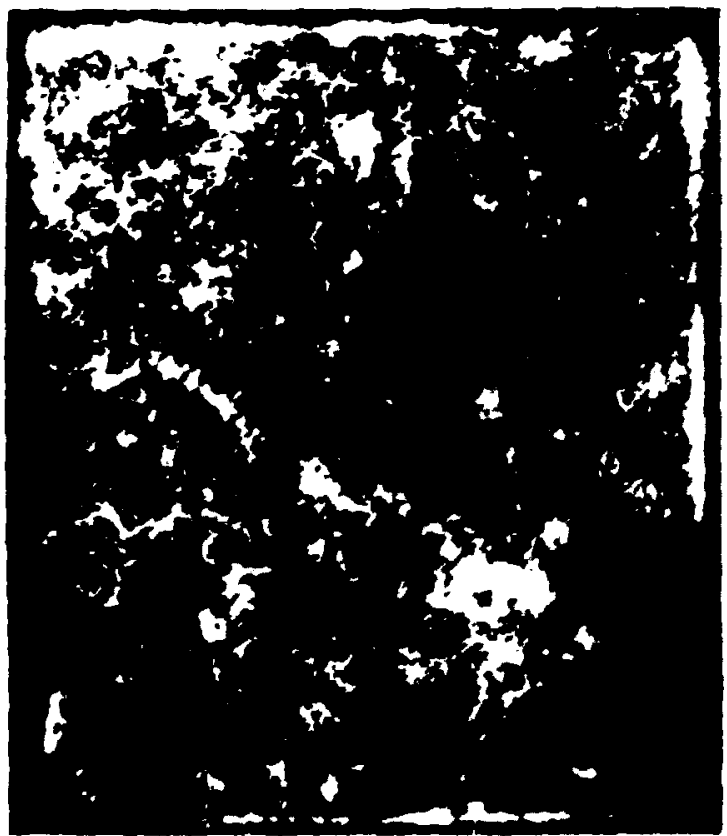

(c) PU IN AERATED SOLUTION

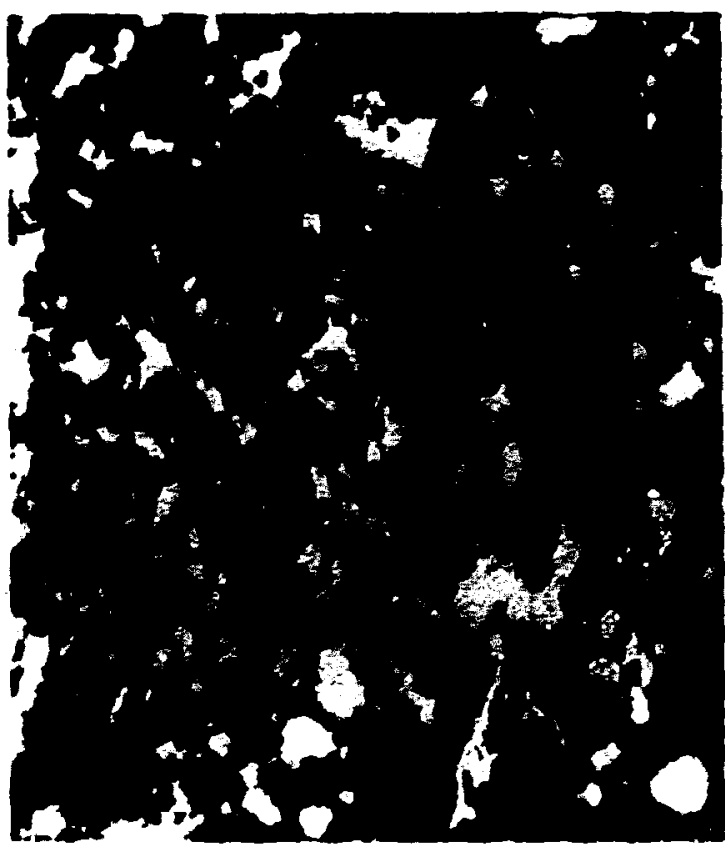

(b) Pu OXIDIZZED WmH O

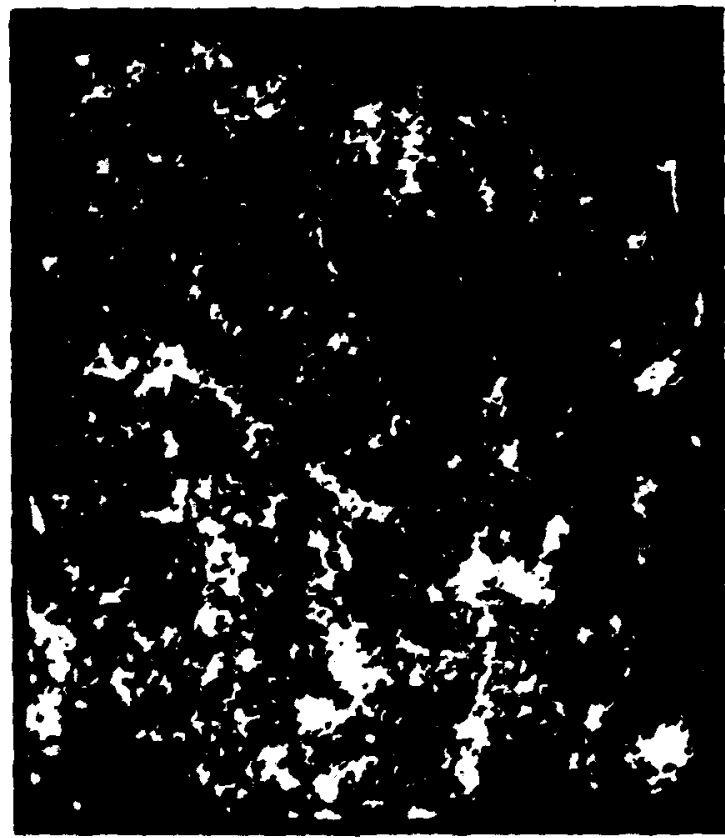

(d) Pu IN NITROgen PURGed SOLUTION

Fig. 9. Sorption of plutoni un from synthetic groundwater. (a) Optical photograph of specimen for comparison; (b) autoradiograph of spectimen after sorption from a groundwater solution oxidi ad with $0_{3} ;(c)$ autoradiograph after sorption from an aerateo solution; (d) autoradiograph after sorption from a nitrogenpurged solution. (All autoradiograph exposures $10 \mathrm{~m}$ ). 
in which these experiments were run would fall at the top of the region observed for granitic mines, as shown by the solid black zone in Fig. 10. Our near-anoxic conditions corresponded to reduction-oxidation potentials in the range of zero to about $-0.1 \mathrm{~V}$, while in deep granitic mines, values of potential as low as $-\mathbf{0 . 3} v$ have been reported. ${ }^{7}$ For such highly negative values of the potential even $\mathrm{\omega O}_{2}{ }^{2+}$ is reduced to $\mathrm{UO}_{2}$, the less mobile form. ${ }^{8}$

It can be concluded from these studies and earlier work on pure minerals ${ }^{2}$ that under aerated granitic groundwater conditions, the prevalent oxidation states in solution for the actinides will be $A_{m}(I I I), P u(I V), U(V I)$, and $\mathrm{Np}(V)$. Under these conditions an appreciable amount of $\mathrm{Np}(\mathrm{V})$ appears to be reduced to $\mathrm{Np}(\mathrm{IV})$ by $\mathrm{Fe}(\mathrm{II})$ containing minerals. The predominant oxidation states in solution for nitrogen-purged solutions will be the same as for aerated solutions, but the reduction of $\mathrm{Np}(V)$ will be enhanced. These studies and the sorption measurements on pure minerals ${ }^{2}$ indicate that the general order of decreasing sorption will be $\mathrm{Pu}(\mathrm{IV})>\mathrm{Am}(\mathrm{III})>$ $N_{p}(I V)>N_{p}(V)>U(V I)$.

The autoradiographs obtained with Np graphically support the reduction mechanism that was proposed previously ${ }^{1}$ for Np and Tc. Further, as mentioned above, the data obtained under nitrogenpurged conditions, which are fatrly mild reducing conditions, indisate that under conditions expected in deep geologic formations, even uranium will be reduced to $\mathrm{UO}_{2}$, the less mobile form (see fig. 10). 


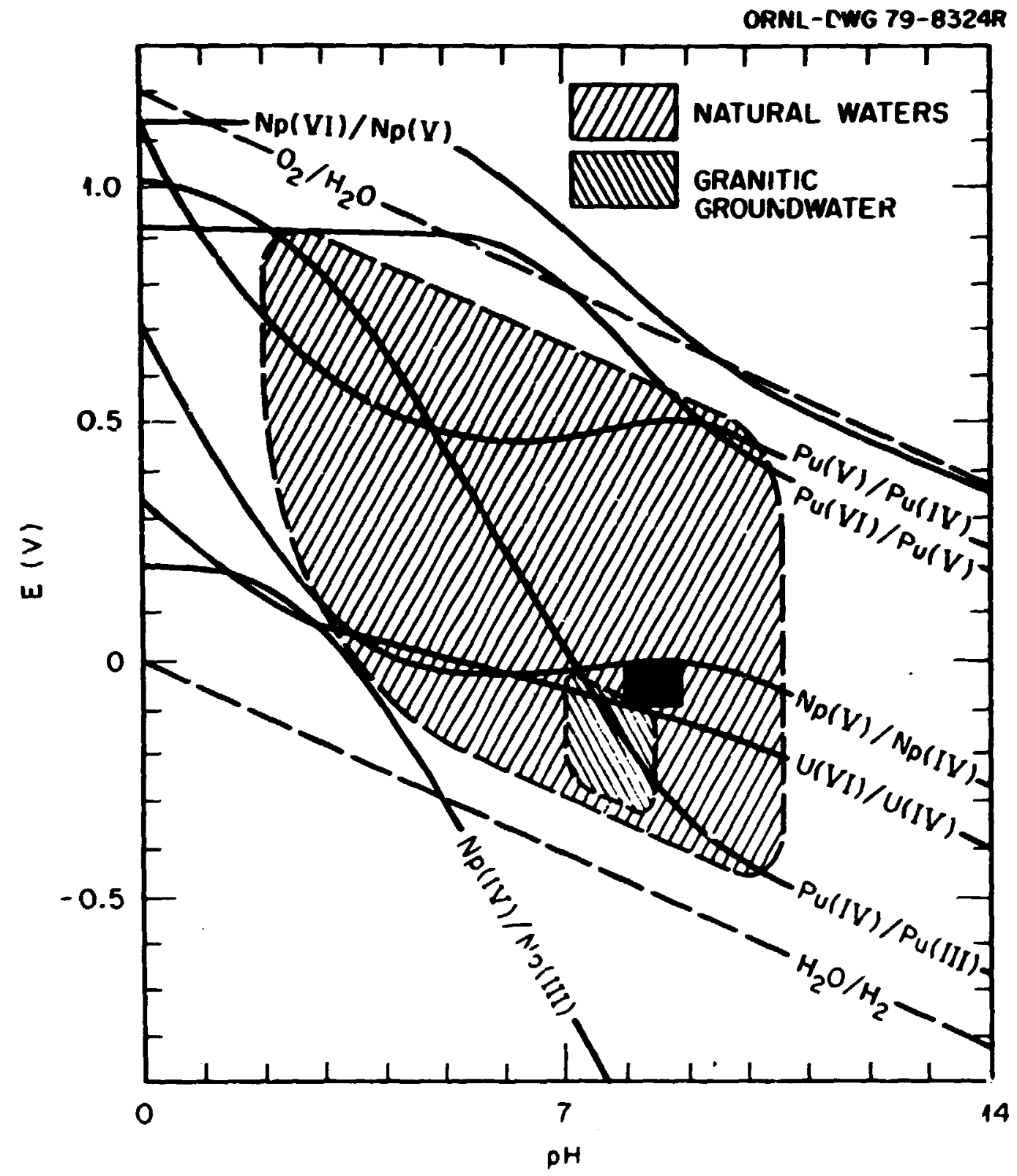

Fig. 10. Potential-pH diagram for soluble species of uranium, neptunium, and plutonium. The solid black zone is consistent with the sorption on granite observed here. 
The sorption of $\mathrm{UO}_{2}{ }^{2+}$ appears to be the only actinide that exhibits a simple cation exchange mechanism. The sorption of $\mathrm{Am}$ (III) and Pu(IV) are dominated by hydrolysis or carbonate complexation reactions.

The sorption of An derived from the autoradiographs also indicates that the sorption data obtained from batch equilibrations of pure minerals can be used to predict sorption on mole rock samples and that grain boundary and fissure effects are not of sufficient importance to alter the sorption markedly.

\section{ACKHONLEDEEMENTS}

The authors wish to express their appreciation to Dr. C. E. Bemis, Jr. for his assistance in the early stages of this work and especially for the design of the autoradiographic camera used. Part of this work was supported (B. Allard) by the Swedish National Council for Radioactive Waste Management and the U. S. Department of Energy, Office of Nuclear Haste Isolation, under contratt with Battelle Memorial Institute's Haste Isolation Safety Assessment Program. 


\section{REFERENCES}

1. Bondietti, E. A. and Francis, C. H., Science, $\underline{203}$ (1979), pp. $1337-1340$.

2. Allard, B., Beall, G. H., and Krajewski, T., "The Sorption of Actinides in Igneous Rocks," Nuclear Technology, in press, 1980.

3. Ames, L. L., PNL-2797/UC-70, "Controlled Sample Program Publicatio No. 1. Characterization of Rock Samples," Oct. 1978.

4. Erdal, B., L.os Alamos Scientific Laboratory, personal communication.

5. Pelzea, J. F., Ames, L. L., Serne, R. J., Fulton, R. H., and Hashburne, C. D. PNL-SA-73!2, 1979.

6. Allard, B., Kipatsi, H., and Liljengin, J. 0., "Expected Species of Uranium, Neptunium, and Plutonium in Neutral Aqueous Solutions," Journal of Inorganic and Nuclear Chemistry, in press, 1980.

7. Allard, B., Rydberg, J., Kipatsi, H., and Torstenfelt, B., "Disposal of Radioactive Waste in Granitic Bedrock," in S. Fried, ed., Radioactive Waste in Geologic Storage, ACS Symposium Series, Arerican Chemicàl Society, Washington, D. C., p. 47.

8. Allard, B., Kipatsi, H., and Torstenfelt, B., "Sorption of LongLived Radionuclides in Clay and Rock, Part II," KBS Technical Report 98, Kärnbränslesäkerhet, Stockholm, 1978. 